\title{
El juez penal y el control difuso: análisis a partir de dos leyes
}

Roger Yon Ruesta

\section{Introducción}

La aplicación de la política social y económica de los distintos gobiernos ha merecido la utilización de diversas formas de control social, desde las más simples, como dación de leyes, hasta otras de carácter más complejo y sofisticado, como el diseño de control a partir de la utilización de medios de comunicación. El control social a través de leyes, en nuestro país, observa una serie de deficiencias técnicas que, realizadas ya sea de manera intencional o negligente, presentan un cuadro controvertido de cara a los postulados constitucionales. Es el caso de la ley que regula la prenda global y flotante y la ley referente a la AFP.

En un primer acercamiento a las precitadas leyes, es curioso notar cómo ambas establecen ilícitos penales en el marco de una regulación civil - comercial y laboral, respectivamente, utilizándose una técnica de remisión inversa en donde no es la ley penal la que busca un complemento en una disposición administrativa, tributaria, civil, laboral, etc.; sino que, por el contrario, son estas disposiciones las que, al estipular incumplimientos, remiten a la ley penal; específicamente, al tipo de apropiación ilícita, regulado en el artículo $190^{\circ}$ del Código penal.

El problema con estas leyes no sólo radica en la deficiente técnica utilizada, sino en que la configuración del tipo de injusto se desliga de la protección del bien jurídico, por lo que, ambas disposiciones legales terminan protegiendo acciones de incumplimiento y estableciendo, detrás de ello, la proscrita cárcel por deudas.

Paralelamente, contamos con jueces cuya actuación traduce defi- 
ciencias de formación, inestabilidad en el cargo, y falta de especialización; asimismo, existen problemas de carácter político como falta de independencia y un poder judicial con serios casos de corrupción. En este marco de actuación de la función jurisdiccional (con honrosas excepciones, por cierto), solicitarle al juez penal que realice la tarea de control difuso, resulta sumamente complicado. Aún así nuestro objetivo -en el presente trabajo- es brindar algunas pautas que guíen al juzgador en la mencionada labor.

\section{El control difuso}

\subsection{Control de constitucionalidad}

El ordenamiento jurídico cumple la misión de regular la vida humana en sociedad, de modo tal que se organiza como una estructura jerárquica. Así, es necesaria una ley que contenga una dirección política, desde la definición de Estado que se quiera adoptar hasta un proyecto de bienestar común; y que, además delimite el ejercicio del poder entre sus detentadores. En suma, una ley que constituya a la vez punto de partida y meta de todo el ordenamiento social ${ }^{1}$.

Esta afirmación abre paso al "principio de supremacía de la Constitución", el mismo que supone la existencia, dentro de todo sistema jurídico, de un orden de prelación de normas, siendo la Constitución, la que rige sobre las demás y en tal sentido, vincula más fuertemente al juez que el resto de las leyes, las cuales únicamente serán aplicadas (serán válidas) si no contradicen los principios fundamentales de aque$11 a^{2}$.

El carácter fundamental de la Constitución, a decir de Lowenstein, se manifiesta en cinco elementos constitutivos irreductibles. Así, toda Constitución que se precie de serlo, deberá contener:

- La diferenciación de las diversas tareas estatales y su asignación a

1 Karl Lowenstein. Teoría de la Constitución. Barcelona. Ariel, 1976. p. 149.

2 Eduardo García de Enterría. La Constitución como norma y el Tribunal Constitucional. Madrid: Civitas, 1985. p. 54. 
diferentes órganos estatales o detentadores del poder para evitar la concentración del poder.

- Un mecanismo preestablecido de cooperación entre los diversos órganos detentadores del poder.

- Un mecanismo de solución autocrática de los conflictos que genere la falencia de cooperación citada en el punto anterior.

- Un método de adaptación pacífica al cambio social (como un método racional de reforma constitucional, por ejemplo).

- El reconocimiento expreso a ciertas esferas de autodeterminación individual -los derechos individuales y libertades fundamentales- y su protección frente a la intervención de uno o todos los detentadores del poder ${ }^{3}$.

El problema que se plantea, entonces, radica en verificar si la norma fundamental se cumple, esto es, si goza de vigencia efectiva; en tal sentido, se deben escoger los medios adecuados para lograr dicho objetivo, porque, definitivamente, una Constitución que no se aplica engendra la desconfianza y el desapego hacia las instituciones jurídicas.

De lo expuesto en el párrafo precedente, se desprende que el dilema principal se encuentra en cómo hacer que la supremacía constitucional no sea tan sólo una declaración retórica. Aquí es donde aparece y se evidencia la necesidad de contar con un sistema efectivo de control de constitucionalidad del aparato infraconstitucional. En otras palabras, de cómo hacer efectivos los límites impuestos al legislador por la norma fundamental.

Toda ley -en los sistemas de constituciones rígidas- debe estar conformada de acuerdo a los principios generales de una ley superior que no puede ser reformada sino a través de un mecanismo especial y por medio de un órgano distinto de los ordinarios. Es en este sentido que se debe entender la presunción que las leyes, en principio, se encuentran en consonancia con la Constitución. La necesidad de mantener la vigencia efectiva de ambos principios ha engendrado el llamado control de constitucionalidad.

Sin embargo, todo lo relacionado con la llamada revisión judicial se torna por momentos confuso. Ello se presenta particularmente en asuntos tales como la legitimidad del control, en los límites del mismo, o 
más aún, cuando nos preguntamos si existen actos exentos del control judicial (por ejemplo en dispositivos judiciales de mero trámite). En tal sentido, el control constitucional es uno de los procesos gubernamentales (legislativos o de interpretación legislativa) menos entendidos.

Es quizá por ello que un problema inherente al control de constitucionalidad, es el de colocar constantemente a los tribunales en conflicto frente a los poderes políticos, lo que ha obligado a ir modelando, en cada época, un concepto distinto de control de constitucionalidad.

El control difuso está íntimamente relacionado con el "principio de legalidad $»^{4}$ y con el Estado de derecho; puesto que, en este último, la premisa esencial es la sumisión de la autoridad política a la ley, y dicha subordinación se logra cuando existe un poder que sea capaz de controlar la legalidad constitucional. El Estado de derecho es, en sí mismo, un Estado controlado desde dentro, por sus propios órganos en recíproca interacción; $y$, desde afuera, por la comunidad gobernada, resultando que el control de constitucionalidad es una de sus herramientas principales $^{5}$.

Sin embargo, a pesar que los gobiernos modernos han coincidido en la necesidad de la existencia de un poder limitado, históricamente no coincidieron acerca de la forma de asegurar ese control. Por una parte, los ingleses y norteamericanos adoptaron el llamado rule of law, donde la responsabilidad del control de gobierno recae fundamentalmente en los jueces, en tanto que los sistemas europeo-continentales optaron, a partir de la experiencia francesa del Consejo de Estado, por el llamado "contencioso- administrativo" ${ }^{6}$.

$4 \mathrm{El}$ principio de legalidad, en esta parte del trabajo, se entiende como " $[. . \mathrm{J}$ el principio de observancia del derecho objetivo en todos los actos de los órganos estatales, así como en toda la actividad desplegada por los titulares de los mismos, incluso los más elevados[...]". Cfr. al respecto: Paolo Biscaretti Di Ruffia. Derecho Constitucional. Madrid: Tecnos, 1973. p. 546.

5 En el estado de derecho el ordenamiento jurídico organiza la respuesta a la violación que no sólo proviene de los ciudadanos particulares, sino también de los funcionarios públicos; así, no es que se restrinja el aparato sancionatorio, sino, por el contrario, el control jurídico se amplía, perfeccionando sus técnicas sancionatorias. Cfr. Norberto Bobbio. Teoría General del Derecho. $4^{\circ}$ reimpresión. Tr. Eduardo Rozo Acuña. Madrid: Debate, 1996. p. 132.

6 Una explicación de ambos sistemas: Eduardo García de Enterría. Op. cit. pp. 49-61. 


\subsection{Definición de control difuso}

El control difuso debe ser entendido en dos sentidos: el primero, es el que le otorga la condición de ser elemento inseparable del concepto de Constitución y se orienta al fin que ésta persigue; el segundo sentido se encuentra relacionado a la pluralidad de medios a través de los cuales ese control se articula, la diversidad de objetos sobre los que puede recaer y el diferente carácter de los instrumentos e institutos en que se manifiesta, los cuales impiden sostener un concepto único de control.

El control difuso es el control judicial, entendido éste como la facultad que se le otorga a los jueces para que puedan disponer la inaplicación de una ley si, a su criterio, resulta inconstitucional, esto es, que contraviene a los principios fundamentales de la Constitución. En tal sentido, este control constitucional opera con la función de todos los jueces, cualesquiera sea su rango y jerarquía.

De conformidad con este sistema, los jueces gozan de poder para declarar la inconstitucionalidad de las leyes atendiendo a que la Constitución es la ley suprema y por tanto se reconoce el principio de su supremacía frente a cualquier otra ley que le sea contraria. En consecuencia, toda ley que la viole o que, de alguna forma la contravenga, será nula y podrá no ser aplicada por los jueces, quienes se encuentran en la obligación de dar prioridad a la Constitución, siempre y cuando, claro está, se aplique al caso concreto.

Sin embargo, pese a lo afirmado en el párrafo precedente, respecto a que normalmente la revisión judicial se adopta para casos concretos y tiene sólo efectos entre las partes en conflicto, se puede dar el caso en que tal decisión judicial siente un precedente que resulte vinculante para todos aquellos tribunales que, en el futuro, se enfrenten a situaciones similares o idénticas. No sólo funciona respecto al resultado de la decisión, sino también al razonamiento mismo.

En tal sentido, la decisión judicial inicial se proyecta hacia el futuro, tanto en el tiempo, vinculando a futuros jueces al resultado del caso y al razonamiento necesario para llegar al mismo, cuanto en el espacio, invitando a futuros jueces a extender el alcance de la decisión inicial, por analogía, a nuevos casos que sean ampliaciones lógicas del principio subyacente en el primer caso. Sin embargo, más adelante comentaremos que lo dicho no se debe cumplir de manera rígida, puesto que la vinculación con el precedente no puede ni debe ser absoluta. 
El control difuso de constitucionalidad de las leyes, deviene en un deber para todos los jueces de examinar la constitucionalidad de sus resoluciones, para el caso concreto, y declarar, cuando sea requerido, su inaplicación dentro del proceso específico que está conociendo. En tal sentido, deberá considerar a dicha ley nula y sin valor para la resolución del caso.

\subsection{Aplicación del control de constitucionalidad}

Si bien no existe ley o reglamento que señale cómo y en qué forma debe ser aplicado el control de constitucionalidad, no obstante, éste se encuentra sometido a ciertas reglas procesales y de fondo que son producto de elaboraciones jurisprudenciales.

Cabe señalar que el control que ejercen los jueces cuenta con algunas limitaciones, tales como la imposibilidad de expresar una opinión adversa a la validez de una ley salvo que sea absolutamente necesaria para la decisión de una causa ante ella. En tal sentido, cuando se solicita la declaración de inconstitucionalidad de una ley se debe poder probar no sólo que la misma es inválida, sino también que se causaría un perjuicio directo o que se generaría un peligro inmediato como resultado de su aplicación.

Por otra parte, consideramos importante tomar en cuenta las reglas a las que debe ajustarse un juez antes de declarar la inconstitucionalidad de una ley, las mismas que fueron descritas por el juez Brandeis, en su voto disidente en Ashwender vs. Tennessee Valley Authority, donde estableció lo siguiente:

- No se puede declarar la inconstitucionalidad en un procedimiento voluntario y no contencioso.

- No se puede anticipar una decisión de inconstitucionalidad antes de la necesidad de decirla.

- No se puede formular una regla de constitucionalidad más amplia que la requerida por los hechos precisos a los cuales ha de aplicarse.

- No se puede entrar a apreciar la constitucionalidad de una ley a instancia de una parte que no ha podido probar que la aplicación de ésta le ocasionaba perjuicio.

- No se puede declarar la inconstitucionalidad de una ley a instancia de una parte que se ha beneficiado con ésta. 
- Una ley siempre debe ser interpretada de forma tal que se evite, en lo posible, su declaración de inconstitucionalidad. Ello, de cara a la presunción de que toda ley es acorde con la Constitución.

\subsection{Base legal}

El principio de supremacía constitucional, como mencionáramos anteriormente, consiste en la cualidad jurídica específica de la Constitución que la define como el sistema normativo de máxima jerarquía dentro del contexto de un sistema jurídico nacional, revistiendo superioridad frente a la totalidad de normas pertenecientes a los diferentes niveles que componen la construcción escalonada del ordenamiento jurídico.

En este sentido, la relación de jerarquía a la que se hace referencia implica la atribución que se le otorga a la Constitución, consistente en una máxima fuerza o capacidad innovativa, por un lado, y a la vez, en la máxima capacidad de resistencia frente a normas sucesivas contrarias a ella. Cabe agregar que, en ambos casos, se hace referencia a los niveles infraconstitucionales.

El principio de supremacía constitucional es pues, un elemento integrante de nuestro sistema constitucional. En ese sentido, la Constitución enuncia:

"Artículo 51\%.- La Constitución prevalece sobre toda norma legal; la ley, sobre las normas de inferior jerarquía, y así sucesivamente. La publicidad es esencial para la vigencia de toda norma del Estado».

Siguiendo lo establecido en este artículo, la constitución prevalece sobre toda norma legal (o con fuerza de ley), esta última, sobre otras de inferior jerarquía, y así sucesivamente. En tal sentido, ha de concluirse que ella reviste mayor jerarquía también sobre los niveles infralegales.

Para garantizar jurídicamente la Constitución, se recurre a los mecanismos de rigidez constitucional y el control jurisdiccional de la constitucionalidad de las leyes y normas infralegales.

Cabe destacar, en primer lugar, que nuestra Carta Magna es de tipo rígida, toda vez que cualquier modificación que requiera, deberá darse a través de un procedimiento agravado contemplado en su artículo $206^{\circ}$. 
"Artículo $206^{\circ}$.- Toda reforma constitucional debe ser aprobada por el Congreso con mayoría absoluta del número legal de sus miembros, y ratificada mediante referéndum. Puede omitirse el referéndum cuando el acuerdo del Congreso se obtiene en dos legislaturas ordinarias sucesivas con una votación favorable, en cada caso, superior a los dos tercios del número legal de congresistas. La ley de reforma constitucional no puede ser observada por el Presidente de la República.

La iniciativa de reforma constitucional corresponde al Presidente de la República, con aprobación del Consejo de Ministros; a los congresistas; y a un número de ciudadanos equivalente al cero punto tres por ciento $(0.3 \%)$ de la población electoral, con firmas comprobadas por la autoridad electoral".

En segundo término, se debe indicar que a efectos de garantizar la vinculatoriedad de la Constitución, se constituyen mecanismos jurídico-procesales que la tutelan frente a actos que la transgreden. Atendiendo a que la Constitución «no es plenamente obligatoria en su sentido técnico", el control jurisdiccional de la constitucionalidad ha contribuido a que el carácter normativo de la Constitución y su preeminencia jerárquica haya alcanzado su forma más neta.

En esta línea, nuestro sistema jurídico establece el control de la constitucionalidad a través de la jurisdicción constitucional, la cual también corresponde al Tribunal Constitucional, conforme lo estipulado en el artículo $201^{\circ}$ de la Constitución. La función que cumple el Tribunal, de acuerdo al artículo $202^{\circ}$ de nuestra Carta Magna, es ejercer el control concentrado de la constitucionalidad de las normas de rango de ley mediante la Acción de inconstitucionalidad.

De vuelta al principio de jerarquía, en concordancia con lo expuesto, el segundo párrafo del artículo $138^{\circ}$ de la Constitución establece:

"Artículo $138^{\circ}$.- La potestad de administrar justicia emana del pueblo y se ejerce por el Poder Judicial a través de sus órganos jerárquicos con arreglo a la Constitución y a las leyes.

En todo proceso, de existir incompatibilidad entre una norma constitucional y una norma legal, los jueces prefieren la primera. Igualmente, prefieren la norma legal sobre toda otra norma de rango inferior».

En el mismo sentido, el artículo $14^{\circ}$ de la Ley Orgánica del Poder Judicial prescribe: 
"Artículo $14^{\circ}$.- De conformidad con el artículo $236^{\circ}$ de la Constitución ${ }^{7}$, cuando los magistrados al momento de fallar el fondo de la cuestión de su competencia, en cualquier clase de proceso o especialidad, encuentren que hay incompatibilidad en su interpretación, de una disposición constitucional y una con rango de ley, resuelven la causa con arreglo a la primera.

Las sentencias así expedidas son elevadas en consulta a la Sala Constitucional y Social de la Corte Suprema, si no fueran impugnadas.

Lo son igualmente las sentencias en segunda instancia en las que se aplique este mismo precepto, aun cuando contra éstas no quepa recurso de casación.

En todos los casos, los magistrados se limitan a declarar la inaplicación de la norma legal por incompatibilidad constitucional, para el caso concreto, sin afectar su vigencia, la que es controlada en la forma y modo que la Constitución establece.

Cuando se trata de normas de inferior jerarquía, rige el mismo principio, no requiriéndose la elevación en consulta, sin perjuicio del proceso por acción popularm.

Todos los jueces tienen la potestad (y más que ello la obligación), de ejercer el control difuso de constitucionalidad y legalidad de las normas. Sin embargo, se debe precisar que la competencia de la jurisdicción constitucional no se circunscribe a los procesos de control normativo, sino que comprende además:

- Procesos de Tutela de Derechos -a través de las Garantías Constitucionales: hábeas corpus, acción de amparo, hábeas data y acción de cumplimiento, reguladas respectivamente por la Ley No 25398 y la Ley No 26301 - procesos que, de acuerdo a los artículos $15^{\circ}$ y $29^{\circ}$ de la Ley $N^{\circ} 23506$, y artículos $1^{\circ}$ y $4^{\circ}$ de la Ley $N^{\circ} 26301$, son de conocimiento de los jueces y Cortes del Poder Judicial, así como del Tribunal Constitucional, pero en este último caso sólo a través del recurso extraordinario de conformidad con lo establecido en el artículo $202^{\circ}$, inciso 2 de la Constitución y artículo $41^{\circ}$ de la Ley Orgánica del Tribunal Constitucional.

- Proceso de conflicto de competencias y atribuciones, de exclusiva competencia del Tribunal Constitucional. 
En consecuencia, la supremacía de la Constitución es protegida a través de los mencionados procesos constitucionales o «Garantías Constitucionales» de conformidad con el Título $\mathrm{V}$ de la Constitución.

En este sentido, todas las normas citadas en los párrafos precedentes, en conjunto, cumplen un rol típicamente instrumental con el objeto de garantizar el respeto del principio de supremacía constitucional.

\section{El delito de apropiación ilícita}

Este tipo penal se encuentra previsto en el Artículo $190^{\circ}$ del Código Penal; específicamente en el Libro Segundo, Título V, Capítulo III, de los Delitos Contra el Patrimonio.

El mencionado artículo establece lo siguiente:

«El que, en su provecho o de un tercero, se apropia indebidamente de un bien mueble, una suma de dinero o un valor que ha recibido en depósito, comisión, administración u otro título semejante que produzca obligación de entregar, devolver, o hacer un uso determinado, será reprimido con pena privativa de libertad no menor de dos ni mayor de cuatro años.

Si el agente obra en calidad de curador, tutor, albacea, síndico, depositario judicial o en el ejercicio de una profesión o industria para la cual tenga título o autorización oficial, la pena será privativa de libertad no menor de tres ni mayor de seis años.

Cuando el agente se apropia de bienes destinados al auxilio de poblaciones que sufren las consecuencias de desastres naturales $\mathbf{u}$ otros similares la pena será privativa de libertad no menor de cuatro ni mayor de $\operatorname{diez}$ años».

El bien jurídico protegido es el patrimonio ${ }^{8}$. Al respecto, el Tribunal Supremo español, en sentencia del 8 de mayo del 1992, determinó que el delito de apropiación indebida ${ }^{9}$ implica un ataque contra el

8 Esto al margen del debate acerca de las diversas concepciones de patrimonio que maneja la doctrina: concepción jurídica de patrimonio, concepción económica estricta de patrimonio, concepción patrimonial personal y la concepción mixta o jurídicoeconómica de patrimonio.

9 El legislador español ha denominado al delito de apropiación ilícita como apropiación indebida. 
patrimonio, entendiendo éste como un conjunto de bienes, derechos y cargas, del que se puede ser titular con carácter de universalidad jurídi$\mathrm{Ca}^{10}$. Un sector de la doctrina nacional, siguiendo el lineamiento internacional, afirma que se protege el patrimonio y, concretamente, la propiedad $^{11}$.

De igual modo, el Tribunal Supremo español ${ }^{12}$ ha resuelto, en la conocida sentencia del 25 de febrero de 1986, de la siguiente manera:

«El delito de apropiación indebida se caracteriza básicamente por la transmutación verificada unilateralmente por el agente en el título posesorio de dinero, cosas muebles o efectos, convirtiendo la posesión jurídica legítima inicial, a la que se había dado paso merced a cualquier relación jurídica habilitadora para ello, en propiedad ilegítima, consecuencia de la deliberada incorporación de aquellos al propio patrimonio, dolo subsiguiente que da al traste y quebranta el basamento de confianza sobre el que se generó la negociación propiciadora de aquel arranque posesorio que puso lícitamente los objetos en mano del infractor ${ }^{13}$.

En relación al sujeto activo, este delito debe ser cometido por quien goza de una especial cualidad; es entonces, un delito especial, es decir, un tipo penal que no cualquier persona puede cometer sino sólo aquellos que posean las especiales exigencias del tipo penal. En este caso, sujeto activo es sólo aquel que ha recibido la cosa ajena en depósito, comisión o administración.

En opinión de Queralt ${ }^{14}$, la apropiación indebida es un delito especial propio ya que sólo podrán cometerlo aquellos que, sin haber reci-

10 Alfonso Serrano Gómez. Derecho Penal. Parte Especial. Madrid: Dikynson, 1999. p. 388.

11 Luis Bramont-Arias Torres y María del Carmen García Cantizano. Manual de Derecho Penal. Parte Especial. Lima: San Marcos, 1998. p. 329.

12 Aunque en España la tipificación de este delito difiere ligeramente a la nuestra, es válido aplicar la jurisprudencia hispana -por la profundidad de su análisis- a nuestra realidad.

13 Tomás Vives Antón. Comentarios al Código Penal de 1995. Volumen II. Valencia: Tirant lo Blanch, 1996. p. 1252.

14 Joan Queralt. Derecho Penal Español. Parte Especial. Barcelona: Bosch, 1996. p. 398 . 
bido en propiedad una cosa tengan la obligación de devolverla en virtud a un título, y estos están taxativamente enunciados en el tipo penal. De esto se desprende que sólo puede ser autor quien ostenta una posición de confianza, determinada legalmente por un doble requisito: la recepción de la cosa y el título que produzca la obligación de entregarla o devolverla.

Cabe resaltar, para efectos de esta investigación, que el primero de estos requisitos: la recepción de la cosa ajena exige la entrega efectiva al deudor. Mediante la entrega, la cosa ajena ha de pasar materialmente a sus manos. No hay, por consiguiente recepción, si la cosa estuvo ya en poder del autor y permanece en su patrimonio [...]. El constitum possesorium o cualquier otro tipo de ficción de entrega no comporta una auténtica recepción de la cosa. Por lo tanto, en tales ocasiones no podrá apreciarse la concurrencia del tipo ${ }^{15}$.

El comportamiento en este delito consiste en la apropiación de un bien mueble, dinero o un valor que se ha recibido en depósito, comisión, administración u otro título semejante que produzca obligación de entregar, devolver o hacer un uso determinado ${ }^{16}$.

Acerca de este punto Serrano Gómez ${ }^{17}$ afirma que la acción consiste en apropiarse o distraer, en perjuicio de otro, dinero, efectos, etc. que se hubieran recibido por cualquier título que produzca la obligación de entregarlos o devolverlos.

Nuestro Código Penal en la tipificación de este delito, determina como conductas delictivas la apropiación indebida de un bien mueble, suma de dinero, o un valor que se ha recibido en depósito, comisión, administración u otro título semejante a éstos. Además, este tipo penal cuenta con dos agravantes; cuando el sujeto tiene la calidad de curador, tutor, albacea, síndico, depositario judicial o en el ejercicio de una profesión o industria para la cual tenga título o autorización oficial, y cuando el sujeto se apropie de bienes destinados al auxilio de poblaciones que sufren las consecuencias de desastres naturales u otros similares.

Así, la conducta consiste en disponer del bien ajeno como si fuera propio, o negarse a devolverlo. La posesión de este bien debe existir en virtud a un título traslativo de posesión, es decir, este delito surge de

15 Tomás Vives. Op. Cit. p. 1255.

16 Luis Bramont-Arias y Otro. Op. cit. p. 329. 
un abuso de confianza que viola una situación jurídica completamente lícita para pasar a otra que, carece de licitud.

El sujeto pasivo en este delito es aquella persona que sufre la lesión patrimonial; el titular del bien jurídico que, en virtud a la confianza, cede la posesión del bien mueble, suma de dinero o valor a otra persona y que se ve sorprendida y dañada por el hacer delictivo del sujeto activo.

\section{La prenda global y flotante}

En un contexto social en el cual el crédito es la herramienta más eficiente en el medio económico para obtener riqueza, surge la necesidad de utilizar mecanismos que garanticen el normal cumplimiento de las operaciones crediticias. Es en este marco en el que se entiende, de manera general, que la prenda es un derecho constituido por el deudor a favor del acreedor con la finalidad de asegurar el cumplimiento de las obligaciones, pero que tiene una característica peculiar: la cosa dada en garantía se transfiere en posesión al acreedor prendario.

\subsection{Prenda sin desplazamiento}

La prenda con registro o sin desplazamiento es una forma de evolución de la prenda tradicional o clásica que representa sobre ésta la gran ventaja desde el punto de vista económico, pues el deudor o tercero no se desprende de los bienes afectados en garantía, de modo que no se ve económicamente perjudicado por la privación del beneficio que se pueda extraer de su uso ${ }^{18}$.

Constituye una figura de derecho real de garantía sobre bienes muebles caracterizado por no implicar desplazamiento de la posesión, sino sujeción registral ${ }^{19}$.

17 Alfonso Serrano. Op. cit. p. 388.

18 Ismael Acevedo y Conrado. Origen y evolución de la prenda sin desplazamiento y sus antecedentes en la legislación extranjera y la del Perú (citado por José Luis Germán Ramírez-Gastón Ballón. La Prenda Flotante. Tesis para obtener el grado de bachiller en derecho. Pontificia Universidad Católica del Perú. 1978. p 77).

19 Jorge Avendaño. Selección de textos. Derechos Reales. Lima: Oficina de Publicaciones para la Docencia de la PUCP, 1996. p. 300. 


\subsection{El contrato de prenda global y flotante}

La Ley $N^{\circ} 26702$ del 06 de diciembre de 1996, conocida como «Ley del Sistema Financiero y Sistema de Seguros y Orgánica de la Superintendencia de Banca y Seguros", ha regulado en su artículo 231० el contrato de prenda global y flotante. El mismo tiene su razón de ser en la necesidad de brindar mayores garantías a los grandes agentes financieros para el cumplimiento de sus operaciones. Este artículo determina lo siguiente:

"Artículo 231\%.- Contrato de prenda global y flotante

Por el contrato de prenda global y flotante se establece un gravamen sobre el bien mueble fungible afecto a la garantía, que permite al constituyente disponer del bien para sustituirlo por otro u otros de valor equivalente. El constituyente de esta prenda o el representante de la persona jurídica queda constituido del bien o bienes, y obligado a devolver otro u otros de la misma especie y cantidad, o en su defecto, su valor en dinero. El depositario que incumpliere con esta obligación se encuentra incurso en el delito tipificado en el artículo $190^{\circ}$ del Código Penal ${ }^{20}$.

Podrá constituirse prenda global y flotante sobre cualquier tipo de activo fungible, para garantizar operaciones objeto de seguro de crédito, de las facturas conformadas o de otras operaciones de crédito.

La prenda global y flotante deberá ser inscrita en el registro especial que se abra en la central de riesgos que, al efecto, organice la superintendencia. El acreedor tiene preferencia absoluta sobre el valor de la prenda global y flotante, y excluye a todos los demás acreedores del constituyente, ya se encuentre este último, o no, afecto a un proceso de reestructuración o concursal».

En la misma línea, el artículo $5^{\circ}$ de la Resolución № 430-97 de la Superintendencia de Banca y Seguros determina que la persona constituyente de la prenda global y flotante, o su representante constituyente, asumen la calidad y responsabilidad del depositario, están obligados a entregar al acreedor los bienes afectados a su simple requerimiento $y$, ante el eventual incumplimiento de la obligación garantizada, configuran el ilícito de apropiación indebida. La entrega

20 El subrayado es nuestro. 
se hace con los mismos bienes o con bienes de igual naturaleza o en su defecto, con la entrega de su valor en dinero. Sin perjuicio de la responsabilidad civil, de no cumplir con la obligación de entrega, el depositario incurrirá en el delito de apropiación ilícita.

En líneas generales, podríamos definir a la prenda flotante como la garantía que puede otorgarse sobre cosas muebles susceptibles de reemplazo por otras de la misma especie y calidad. Estos bienes necesariamente deben ser utilizados en su explotación económica por lo que la desposesión se torna imposible, ya que acarrearía la paralización de la actividad productora o comercializadora del deudor. Se entiende que con este tipo de prenda flotante se busca, por un lado, la seguridad para los acreedores a través de la publicidad de la prenda constituida y, por el otro, evitar que se alteren las condiciones empresariales del deudor.

Entonces, la denominada "prenda flotante» permite gravar un conjunto de bienes no registrables, conservando el deudor la posesión de los mismos y estableciéndose la facultad para que pueda comercializarlos libremente, con la única limitación de obligarse a reponer los bienes vendidos, por otros de la misma especie, manteniendo así el stock original $^{21}$.

Puede decirse que la garantía del acreedor no recae sobre cuerpos ciertos sino sobre un género en constante cambio imprimiéndole a la garantía una gran flexibilidad que sólo se inmovilizará en el momento de la ejecución. ${ }^{22}$

Cabe indicar que, la prenda flotante, a diferencia de la prenda tradicional, presenta características propias. En la doctrina argentina se suele establecer como uno de los requisitos de la prenda flotante que las cosas gravadas sean mercadería y materia prima que generalmente pertenecen a un establecimiento comercial e industrial. En tal sentido, no se trata de cualquier clase de mercancía o materia prima, sino que deben estar relacionadas con el movimiento económico de la industria o el comercio ${ }^{23}$.

Por su finalidad económica, las mercaderías gravadas están destinadas a enajenarse o transformarse, teniendo el deudor la libre disponibi-

21 Luis Pizarro Aranguren. "Aproximación al sistema de garantía prendaria en el Derecho peruano". En: Ius Et Veritas N¹3. Año VII. 1996. p. 133.

22 José Luis Ramírez-Gastón. Op. cit. p. 79.

23 Ibid. p. 73. 
lidad de ellas. Una vez enajenadas el derecho de garantía no sigue a la cosa, sino que recae sobre las que se adquieren para reemplazarlas, por lo cual el derecho del acreedor se efectivizará normalmente sobre otras que no son las primitivamente gravadas.

Por ser susceptibles de reemplazo por objetos de la misma especie y calidad, estos bienes tienen carácter de fungibles, cuya función esencial es asegurar la perdurabilidad de la prenda. En tal sentido, la prenda global y flotante es una ficción del Derecho Civil frente a determinadas conductas comerciales.

Entre los caracteres de la prenda flotante tenemos que es convencional, sólo puede constituirse por el acreedor de parte que es precisamente el que le da nacimiento; es accesoria, no se concibe sino como accesoria de una obligación principal a la cual garantiza; es mobiliaria, recae sobre un conjunto de bienes muebles; es indivisible, ya que cada uno de los bienes pignorados se encuentran afectados en el conjunto de la deuda y de cada parte de ella, salvo pacto en contrario. ${ }^{24}$

En la Resolución de la Superintendencia anteriormente citada, se designa al propietario del bien prendado como depositario del mismo, y cuando es exigido a devolver la prenda o un valor semejante sin que esto suceda, se le imputa haberse apropiado de algo que le pertenece. Como ya hemos expuesto en párrafos precedentes, esta situación degenera la figura de la apropiación ilícita. La conducta criminalizada en la Ley $N^{\circ} 26702$ y la Resolución de la Superintendencia de Banca y Seguros No 430-97 no es compatible con las exigencias inherentes a la naturaleza de este delito.

Cabe señalar que algo similar ocurre en España con el artículo 59 de la Ley de Hipoteca Mobiliaria y Prenda sin Desplazamiento de 1954, la que dispone que «el dueño de los efectos pignorados, a todos los efectos legales, tendrá la consideración de depositarion. En virtud a lo anterior, los jueces españoles castigaron como apropiación indebida la disposición de los bienes prendados efectuada por el propio propietario. Pero, como se ha repetido en la doctrina, ni el propietario comete, en puridad, apropiación, ni puede decirse que haya recibido material y efectivamente la cosa prendada ${ }^{25}$. De lo anterior se desprende la exis-

24 Ibid. pp. $80-81$.

25 Tomás Vives. Op. cit. p. 1264. 
tencia de un conflicto entre la doctrina penal mayoritaria ${ }^{26}$ y el legislador, quien, en busca de otorgar mayores garantías al acreedor prendario ha buscado una solución fácil sin medir las consecuencias.

El supuesto ilícito, mencionado artículo $231^{\circ}$ de la ley $\mathrm{N}^{\circ} 26702$, es calificado como ampliación de la punibilidad, es decir, el campo de punición del delito de apropiación ilícita se ha ampliado. Esto, mediante la figura de la remisión inversa, recurso legislativo bastante criticado en sede penal y que implica una propuesta totalmente antitécnica por las consecuencias negativas que puede acarrear de cara al principio de legalidad.

Así, mediante esta remisión, se está "llenando" de un nuevo contenido, totalmente ajeno a la naturaleza del tipo de apropiación ilícita. En efecto, se criminaliza el incumplimiento de la obligación de devolver, derivada de la celebración del contrato de prenda global y flotante. ¿Acaso el Derecho Penal será el encargado de sancionar este tipo de incumplimientos contractuales?. Creemos que no. No sólo se está desnaturalizando el delito de apropiación ilícita, sino que, además, se malinterpreta la función del derecho penal: defensa y protección de bienes jurídicopenales. En esta línea de pensamiento Muñoz Conde indica:

"[...] el bien jurídico protegido en estos delitos sui generis creados por leyes especiales, es por tanto, el derecho que tiene quien entrega una cosa a que sea usada conforme al ámbito de disponibilidad que permita el título por lo que fue entregada la cosa, ámbito de disponibilidad que puede coincidir con una propiedad con limitaciones. La esencia de estos delitos consiste en la lesión a este derecho con el incumplimiento, por parte del sujeto activo de la obligación de disponer de la cosa con las limitaciones que en el título se indican; de este modo, creándose delitos que sólo tienen con la apropiación indebida un parentesco morfológico y que sólo se asimilan a ella a efectos penales, se amplia el ámbito de protección penal, sancionando el mero incumplimiento contractual o la afectación de ciertas expectativas y limitaciones $[\ldots]{ }^{27}$.

26 Cfr. entre otros: Juan Bustos Ramírez. Manual de Derecho Penal. Parte Especial. Barcelona: Ariel, 1991. Francisco Muñoz Conde. Derecho Penal. Parte Especial. Valencia: Tirant lo Blanch, 1996. José María Rodríguez Devesa. Derecho Penal. Parte Especial. Madrid: Dikynson, 1996. Joan Queralt. Derecho Penal Español. Op. cit.

27 Francisco Muñoz. Op. cit. p 380. 
Por otra parte, lo que aparece especialmente protegido en el delito de apropiación ilícita es la propiedad sobre una cosa mueble y en relación a ésta, la capacidad de disposición que tiene el propietario y que implica que tenga derecho a su restitución y como contrapartida que exija "al otro" la obligación de restituir la cosa. ${ }^{28}$

En tal sentido, si el bien jurídico protegido es la propiedad, la ley, al otorgarle al deudor opción de cumplir con su obligación pagando al acreedor el equivalente en dinero del bien prendado, se desprende que lo que se busca proteger no es la propiedad del bien (cuyo titular sigue siendo el deudor), sino únicamente el cumplimiento de la obligación de pago, lo cual no es objeto de protección de esta figura penal.

Además, debe considerarse que en el campo del derecho penal se protege al titular del bien jurídico. En este caso correspondería proteger al propietario del bien (deudor); por el contrario, en la ley comentada, se busca proteger al acreedor, específicamente, el cumplimiento de la acreencia o el pago del equivalente al bien prendado.

\section{El pago de AFP: artículo $35^{\circ}$ de la Ley $\mathrm{N}^{\circ} 25897$, modificado por Ley $\mathrm{N}^{\circ} 27130$.}

"Artículo 35०.- Cuando el empleador no cumpla con el pago oportuno de los aportes al Sistema Privado de Pensiones, deberá formular una «Declaración sin Pago" de los mismos, dentro del mismo plazo que tiene para efectuar el pago de los aportes del trabajador, utilizando el formato que designe la Superintendencia de AFP.

El incumplimiento de la obligación de formular dicha declaración por parte del empleador, o la formación incompleta de la misma, será sancionado por la Superintendencia de AFP con multa equivalente al 10\% (diez por ciento) de la UIT vigente a la fecha de pago, por cada trabajador cuyos aportes no fueran declarados.

Sin perjuicio de las sanciones, multas o intereses moratorios que pudieran recaer sobre el empleador por la demora o el incumplimiento de su obligación de retención y pago, el trabajador, la AFP y/o la Superintendencia pueden accionar penalmente por delito de apropiación ilícita contra los representantes legales del empleador, en el caso 
de que en forma maliciosa incumplan o cumplan defectuosamente con su obligación de pagar los aportes previsionales retenidos".

Nuevamente nos encontramos ante el problema de compatibilizar los requisitos típicos del delito de apropiación ilícita con el comportamiento criminalizado en la «Ley del Sistema Privado de Administración de Fondos de Pensiones".

El artículo $35^{\circ}$ de la mencionada ley criminaliza la demora o el incumplimiento de la obligación de retención y pago de los aportes de los trabajadores, por parte del empleador, a este acto de incumplimiento esta ley la ha denominado apropiación ilícita.

En el caso de la supuesta apropiación ilícita por el no pago de los aportes del trabajador a la AFP, el ilícito se configuraría cuando luego de que el empleador entregase de manera ficta al trabajador una parte de su remuneración destinada al aporte de la AFP, y que este monto fuera nuevamente entregado al empleador para que éste, finalmente, lo deposite en una cuenta especial del sistema financiero, no cumple con esta obligación.

Frente a esta decisión legislativa se debe reiterar que, para haber recibido la cosa en depósito, comisión o administración u otro título semejante que produzca la obligación de entregarla o devolverla, antes se debe haber producido la entrega de la cosa. Así, no existe tal entrega si la cosa ya estaba en poder del presunto autor y permanece en su patrimonio. En este sentido coincidimos con Muñoz Conde cuando afirma que el sujeto activo de este delito debe estar en posesión de la cosa apropiada pero, que la cuestión, materia de discusión, es el alcance de tal posesión.

Sobre este punto las opiniones se encuentran divididas; por un lado se puede optar por un alcance amplio de la posesión es decir, admitir la aplicación en el Derecho penal del constitum possesorium, o lo conocido en el Derecho privado como entrega ficta, como lo ha hecho el Tribunal Supremo español en su sentencia del 24 de febrero de 1986, la cual determina lo siguiente:

«El empresario, tanto a título personal como en el de una Sociedad, obligado a retener, de los salarios o sueldos, las cuotas obreras de la Seguridad Social, en virtud de la normativa laboral está investido de un mandato o encargo de cobro, a través del cual se opera la modifi- 
cación del título de poseer, pues su carácter dominical se transforma en el de mandatario o depositario de las sumas retenidas para su entrega inmediata a los organismos de la Seguridad Social, y ello puede originar el delito de apropiación indebida [...]».

Por otro lado, se opta por un concepto más restringido, como aquél que exige la entrega efectiva de la cosa mueble ajena, entendiendo que esta entrega engloba el dominio material del bien, es decir, que se encuentre físicamente a disposición del poseedor.

Somos de la opinión que la primera de estas opciones no es aceptable. Ello, porque se debe mantener la protección del bien jurídico tutelado en el tipo de apropiación ilícita. En efecto, admitir la entrega ficta significa considerar que el monto correspondiente al pago del aporte de AFP se incorporó al patrimonio del asegurado cuando en términos reales nunca dejó de integrar el patrimonio del empleador; dicho «aporte» siempre estuvo en su esfera de dominio y disponibilidad. Además, aceptar la entrega ficta acarrearía la confusión de lo que es objeto de protección en el tipo de apropiación ilícita.

Así, de proteger la propiedad se pasaría a proteger la obligación de pago o la no demora en que éste se efectúe. Obligaciones que no se condicen con el bien jurídico protegido, de tal forma que la intervención del Estado, a través del Derecho penal, conllevaría al control social de aquellas conductas que incumplan con dicha obligación; lo que, entendemos, amplía la participación del Estado a comportamientos que no guardan relación con la gravedad y configuración típica de la apropiación ilícita. En tal sentido, también se estaría vulnerando el principio de mínima intervención.

Lo anteriormente expuesto no desestima la importancia de la seguridad social, sólo pretendemos resaltar que los comportamientos que se pretenden sancionar no pueden ser subsumidos en tipo descrito en artículo $190^{\circ}$ del Código Penal.

En relación a lo anteriormente expuesto debe mencionarse que la demora en el pago de la AFP como situación de peligro, colisiona con la consumación de la apropiación ilícita por tratarse este último de un delito de resultado, por lo que los comportamientos descritos en la Ley de AFP devienen en vagos e imprecisos, lo que a su vez, al ser aplicados por los operadores de control social (policía, ministerio público, etc.) puede dar paso a criminalizar conductas por vía de la analogía (la de- 
mora en el pago de una indemnización de seguro) o por responsabilidad objetiva (cuando se califique, por ejemplo, el incumplimiento defectuoso, previsto en el artículo $35^{\circ}$, ¿será el caso del pago en una cuenta bancaria equivocada?).

En opinión de Bustos Ramírez:

«[...] en este caso nos encontramos en los límites de la apropiación indebida, tanto en razón de la especial realidad del título como por el hecho que se trata de dinero y, por tanto, también en los límites de la argumentación jurídica y en que si bien desde un punto de vista político-criminal nos inclinamos de lege lata por la existencia de una apropiación indebida, pues el empleador ha perdido la disponibilidad absoluta sobre una cantidad de dinero que ha sido asignada a un fin en virtud de un contrato laboral, que es la esencia de la apropiación indebida, tampoco se puede desconocer la complejidad fáctica sobre la cual se aplica la norma, lo cual hace que nuestra solución no sea totalmente satisfactoria. De ahí que sea necesaria una solución legislativa expresa $[\ldots] \aleph^{29}$.

$\mathrm{Al}$ respecto nos permitimos discrepar con el distinguido profesor chileno por considerar que los argumentos de necesidad responden a una política-criminal empírica, como la impulsada en su momento por Von Liszt quien la señala como un conjunto de estrategias ordenadas a una lucha eficaz contra el delito, mientras que una política-criminal valorativa (con la que estamos de acuerdo), según Silva Sánchez, implica analizar la intervención punitiva:

«[...] no sólo desde el punto de vista de la eficacia preventiva, sino también, y muy significativamente, desde el punto de vista de la adaptación a tal intervención a los principios de proporcionalidad, subsidiaridad, fragmentariedad y exclusiva protección de bienes jurídicos, entre otros que caracterizan la intervención del derecho penal en el Estado social y democrático de Derecho [...] ${ }^{30}$.

29 Ibid. p. 207.

30 Jesús María Silva Sánchez. «Política criminal y Sida». En Revista Peruana de Ciencias Penales, Año II, enero-julio, 1994, pp. 347-348. 
Las entregas fictas, si bien son de uso frecuente en el Derecho privado porque facilitan transacciones comerciales, no pueden ser trasladadas mecánicamente e incorporadas irreflexivamente al derecho penal, puesto que, de ser así se puede perder de vista el objeto de protección del tipo penal, como ocurre en el presente caso. A ello debe sumarse el hecho que siendo el derecho penal la ultima ratio, es decir, aquella última instancia de control de las relaciones sociales (es la rama del derecho que aplica las sanciones más graves), para imponer esta sanción no podemos recurrir a ficciones o presunciones, puesto que se terminaría protegiendo sólo la antijuricidad formal.

El Derecho penal sanciona conductas típicamente antijurídicas, explicitadas en peligro o afectación de bienes jurídicos -afectación de la antijuricidad material-, ya que de lo contrario se relativizaría el mensaje normativo al incluirse comportamientos incompatibles o difícilmente subsumibles en la norma jurídico-penal invocada.

\section{La prenda global y flotante y el pago de la AFP: vulneración de principios constitucionales}

La evolución del Derecho penal y el carácter normativo de la Constitución van de la mano. Esta última, a medida que es considerada como norma vigente (y no como un mero instrumento de carácter político), ha influenciado notoriamente en el legislador, como en el juez, tanto en la creación de nuevos tipos penales como en la interpretación de los ya existentes, a partir de la delimitación de las políticas a seguir y de criterios para la interpretación de dichas normas penales, según sea el caso. Cabe señalar que esta «irrupción» de la Constitución en el campo penal se da en todos los aspectos, no sólo respecto de los operadores jurídicos ya señalados, sino también obligando al «científico del derecho» a replantear la visión de su ciencia ${ }^{31}$.

Esto ha llevado a autores como Carbonell, desde una perspectiva constitucionalista, a conceptualizar el derecho penal como:

31 Ignacio Berdugo Gómez De La Torre y Otros. Lecciones de Derecho Penal. Parte General. Barcelona: Praxis, 1997. p. 33. 
«[...] la parte del Ordenamiento jurídico, reguladora del poder punitivo del Estado, que, para proteger valores e intereses, con relevancia constitucional, define como delitos determinadas conductas a cuya verificación asocia como consecuencias jurídicas penas y/o medidas de seguridad $[\ldots] »^{32}$.

Así pues, la lectura de los problemas generados en relación a las normas que regulan la prenda global y flotante y la no aportación a la AFP, debe hacerse desde una perspectiva «constitucionalista». Es decir, teniendo en consideración los postulados, principios y garantias planteados en la Constitución como soporte para el sistema punitivo estatal: el Programa de Derecho Penal Constitucional. Es en este orden de ideas que podemos desarrollar las siguientes criticas a las mencionadas normas.

\subsection{Principio de legalidad}

Como principal pilar del Derecho penal liberal, se encuentra el principio de legalidad. El mismo responde a la necesidad de limitar y controlar la facultad sancionadora del Estado, ya que esta rama del ordenamiento jurídico ha sido utilizada para objetivos ajenos a la defensa de la persona y su interrelación en sociedad. Así, un Estado de derecho debe proteger al individuo no sólo mediante el Derecho penal, sino también del Derecho penal; es decir, que el ordenamiento jurídico no sólo ha de disponer de métodos y medios adecuados para la prevención del delito, sino que también ha de imponer límites al empleo de la potestad punitiva, para que el ciudadano no quede desprotegido y a merced de una intervención arbitraria o excesiva del Estado Leviatán ${ }^{33}$.

Este principio, que se engloba en el aforismo nullum crimen, nullum poena sine lege, se encuentra consagrado constitucionalmente en el artículo $2^{\circ}$, inciso 24 , literal d, el cual a tenor determina lo siguiente:

32 Juan Carlos Carbonell Mateu. Derecho Penal: Concepto y principios constitucionales. Valencia: Tirant Lo Blanch, 1996, p. 27.

33 Claus Roxin. Derecho Penal. Parte General. Fundamentos. La estructura de la teoría del delito. Traducción de Diego-Manuel Luzón Peña y Otros. Madrid: Civitas, 1997, p. 137. 
«Nadie será procesado ni condenado por acto u omisión que al tiempo de cometerse no esté previamente calificado en la ley, de manera expresa e inequívoca, como infracción punible; ni sancionado con pena no prevista en la ley».

Además, está plasmado en el artículo II del Título Preliminar del Código Penal, el cual determina lo siguiente:

«Nadie será sancionado por un acto no previsto como delito o falta por ley vigente al momento de su comisión, ni sometido a pena o medida de seguridad que no se encuentren establecidas en ella».

En este sentido, sólo será de relevancia penal todo aquello que se encuadre dentro del texto de la ley. En nuestro país, lamentablemente, se ha entendido este principio señalándose que las normas penales deben aplicarse mecánicamente, no pueden ser materia de interpretación. Nada más incorrecto que lo anterior, las normas penales también se interpretan, y se interpretan y aplican dentro del marco constitucional.

El principio de legalidad expresa cuatro consecuencias; la prohibición de analogía, la prohibición de derecho consuetudinario para fundamentar o agravar las penas, la prohibición de retroactividad, y la prohibición de leyes penales indeterminadas (cuya excepción está dada por los tipos penales abiertos y la ley penal en blanco) ${ }^{34}$.

Así, en estas consecuencias se establece que sólo serán materia penal aquellas conductas que se encuadren dentro de lo criminalizado en el tipo penal y que, esta criminalización debe ser clara y exacta, es decir, se debe determinar con exactitud lo prohibido y sancionado.

Las leyes comentadas aparentemente estarían postulando una analogía ${ }^{35}$; sin embargo, no es así, se está integrando un supuesto de hecho previsto expresamente en una norma extrapenal.

34 Al respecto véase Claus Roxin. Op. cit. pp. 140-141. Reinhart Maurach, y Heinz Zipf. Derecho Penal. Parte General. Tomo I. Buenos Aires. Astrea: 1987. pp. 157-164.

$35 \mathrm{Al}$ respecto ver: Diego Manuel Luzón Peña. Curso de Derecho Penal. Parte General. Madrid: Universitas, 1996. p. 137. Para quien "[...] la analogía supone un procedimiento de creación o integración del derecho por el juez, cierto que no de modo absolutamente libre, sino por referencia a una ley, por ser el supuesto de hecho, que no encaja en la definición legal (de un delito o de una agravación del mismo, en este caso), similar o análogo previsto legalmente [...]». 
De otro lado, «[...] al supuesto de hecho de toda norma jurídico penal le corresponde describir el comportamiento antijurídico o hacer constar lo que se conoce con el nombre de "materia de prohibición" $\left[\ldots . . w^{36}\right.$; sin embargo, en algunos tipos penales denominados leyes penales en blanco esta conducta, prohibida u ordenada por la norma, no está predeterminada por el supuesto de hecho sino que hay una carencia que «[...] supone la omisión o al menos la no referencia explícita de aspectos relativos a la acción u omisión prohibida [...] $w^{37}$. Esta característica hace necesaria la remisión a una norma de igual o menor jerarquía que permita completar este supuesto de hecho; así, pueden ser concebidas como "[...] que dejan sin embargo su integración a otras leyes, reglamentos o incluso actos administrativos $[\ldots]]^{38}$. La ley penal en blanco, entonces, se constituye como una figura que aparece ante la incompletud o ambigüedad de un término jurídico penal.

La ley penal en blanco es un tipo de remisión legislativa que se estima como necesaria dentro de nuestro ordenamiento jurídico; tiene como finalidad el generar normas jurídico penales más ágiles y más acordes con la realidad cambiante y efímera que hoy en día envuelve a una sociedad en continuo "progreso". Esta agilización se alcanzaría por medio de remisiones a normas de índole administrativo o ejecutivo, entre otras, las cuales, debido a lo complejo de la temática que se busca penalizar o a lo cambiante de su modalidad, resultan ser la forma más apropiada para completar una tipificación de otro modo muy extensa o confusa.

La remisión a la que se da lugar en la ley penal en blanco puede ser tanto de carácter descriptivo, si lo que se busca es entender el significado concreto de cierta palabra que se encuentra definida en una normativa extrapenal, o de carácter prescriptivo, cuando se refiere a situaciones que el artículo no especifica pero en los que se basa para plantear la penalidad o criminalidad del hecho ${ }^{39}$.

36 Antonio Doval Pais. Posiblidades y límites para la formulación de las normas penales. El caso de la ley penal en blanco. Valencia: Tirant lo Blanch, 1999. p. 129.

37 Ibidem.

38 Claus Roxin. Op. cit. p. 465.

39 Ver: Carlos Martínez- Buján Pérez. Derecho Penal Económico. Parte General. Valencia: Tirant lo blanch, 1998. p. 126. 
La técnica legislativa de las leyes penales en blanco acarrean, sin embargo, una desmembración de la norma penal que ocasiona como problema fundamental un aspecto que versa sobre la indeterminación de aspectos relativos a la conducta prohibida «[...] que se manifiesta en la eficacia preventiva de la ley penal $[\ldots] \|^{40}$.

Sobre esta problemática es evidente que la dificultad de conocimiento de aquello que se encuentra prohibido, en tanto que no se desprende del supuesto de hecho de la norma jurídico penal, afecta directamente al principio de legalidad $y$, en este sentido, a la seguridad jurídica, la misma que implica que "[...] una sanción no pueda ser impuesta si no descansa en una base legal, clara y no ambigua $[\ldots] x^{41}$. Esta consecuencia genera problemas mayores cuando la remisión a normas extrapenales se hace a una instancia inferior a la ley ya que:

«[...] la técnica de remisión a leyes inferiores tiene como efecto necesario el que el contenido de la ley penal pueda ir variando por la sola voluntad de la administración, con lo cual se modifica de facto el tipo penal sin la necesidad de acudir a los conductos legislativos ordinarios $[\ldots] n^{42}$.

En el problema de indeterminación de las leyes penales en blanco hay, sin embargo, una clase de remisión en la cual "[...] existe una absoluta ausencia de concreción en el tipo penal, de tal modo que éste se limita simplemente a establecer la sanción y relega la determinación de toda la esfera de lo punible a una instancia diferente $[\ldots]{ }^{43}$. Son las denominadas cláusulas de remisión inversa.

En la remisión inversa el problema se centra en que la ubicación del núcleo esencial de lo prohibido no se encuentra en la propia norma penal y que, por lo tanto, no es ésta la que establece la conducta que debe ser sancionada; sino, por el contrario, esta función se lleva a cabo por ámbitos distintos al derecho penal.

40 Antonio Doval Pais. Op. cit. p. 130.

41 Adán Nieto Martín. Fraudes Comunitarios. Tratado Penal Económico Europeo. Barcelona: Praxis, 1996. p. 124.

42 Antonio Doval Pais. Op. cit. p. 163.

43 Carlos Martínez-Buján Peréz. Op. cit. p. 123. 
"[...] la conformidad constitucional de una ley penal en blanco se ha hecho depender [...] de que el legislador penal fije en la ley lo que se ha denominado como el "núcleo esencial de la prohibición" y se satisfagan las exigencias de certeza. La corrección de una ley tal dependerá, en consecuencia, de que la remisión que contiene no se refiera a aspectos pertenecientes a los elementos básicos o esenciales de aquello que se prohibe, sino a otros que se dicen "complementarios" [...]"

De esta afirmación se puede colegir que los atributos principales con los que debe contar toda norma jurídico penal son aquellos que se desprenden del principio de legalidad, por medio de lo cual se establece que ésta (norma) debe determinar de una manera estricta y "precisa" el supuesto de hecho punible. Es este «[...] postulado de precisión de la ley el que al dar lugar al llamado "mandato de determinación", que exige que la ley determine de forma suficientemente diferenciada las distintas conductas punibles y las penas que pueden acarrear [...]" ${ }^{45}$, el que se constituye así como un aspecto material del principio de legalidad, que pretende la no vulneración de la seguridad y garantía de los enunciados penales.

Es así que a través de la remisión inversa se establece la ampliación del radio de penalización prescribiendo una conducta que no encaja en el tipo original.

Por último, la remisión inversa vacía a la norma penal de la motivación esencial que ésta debe poseer; la norma penal busca motivar la conducta de los sujetos para adecuarla a los parámetros que por medio de ella el Estado considera como apropiados, busca que la gente interiorice ciertas actitudes y así se abstenga de delinquir. Al plantear el núcleo de lo prohibido fuera de la norma que debe apuntar a esta motivación, esta función de la norma se perdería, pues se llegaría a reprimir comportamientos diferentes a los contenidos en la norma jurídico-penal atribuyéndoles el mismo noumen juris.

Debemos poner énfasis en la falta de coherencia que se da entre estos tipos de remisión y el principio de legalidad que nuestra carta constitucional recoge. Las remisiones inversas atentan contra la certeza,

44 Antonio Doval Pais. Op. cit. p.165.

45 Santiago Mir Puig. Derecho Penal, Parte General. Cuarta Edición. Barcelona: PPU, 1996, p. 78. 
precisión, taxatividad y carácter motivador que todo norma de índole penal debe poseer. También resulta necesario incidir en que, generar normas de esta vaguedad y fragilidad llevarían a un mayor reconocimiento del error. Como ha señalado Adan Nieto (en cita de Muñoz Conde), "[...] de la poca precisión del legislador al describir las conductas debe derivarse un mayor reconocimiento del error, pues, no es el ciudadano quien debe pagar las consecuencias de una desafortunada técnica legislativa $[\ldots])^{46}$.

Finalmente, queda claro que las remisiones inversas contravienen el marco constitucional y los aspectos mínimos de garantía para el ciudadano, máxime si la remisión es a normas penales que ni siquiera son leyes penales en blanco, como es el caso del tipo de apropiación ilícita. ${ }^{47}$

\subsection{Principio de mínima intervención}

Muchos años atrás, Radbruch ${ }^{48}$ postuló que lo ideal no era un derecho penal mejor, sino algo mejor que el derecho penal. A nuestro entender, ello tiene sustento en que el derecho penal afecta siempre a derechos fundamentales de la persona, es decir, supone una muy grave injerencia del Estado en la vida y el desarrollo de la personalidad de los ciudadanos. Por ello, en la actualidad, la doctrina española mayoritaria se sustenta en este hecho para afirmar que las normas penales deben estar acorde con el desarrollo de los derechos fundamentales y de las libertades públicas ${ }^{49}$, puesto que lejos de constituir una forma de control social radical:

«[...] el fenómeno punitivo no constituye un expediente metafísico (ni simbólico, habría que añadir ahora), sino "una amarga necesidad en la comunidad de seres imperfectos que son los hombres" $[. . .]^{50}$.

De ese modo, según Carbonell, si se tiene en cuenta que sólo es posible limitar las libertades para tutelar libertades, y que la función

46 Adán Nieto. Op. cit. pp. 129-130.

47 Claus Roxin Op. cit. p.169, quien ha resaltado que, por lo menos, "Teóricamente también resulta indiscutido que por indeterminación las disposiciones penales pueden ser inconstitucionales y por lo tanto nulas».

48 Juan Carbonell. Op. cit. p. 194.

49 Ibid. p. 34. 
del Derecho penal es conseguir la mayor libertad posible, entonces resulta inadecuado afectar los derechos constitucionales de la persona para proteger otros de inferior rango ${ }^{51}$. Es decir, el Derecho penal sólo tendrá legitimidad para intervenir cuando sea eminentemente necesario, cuando no sea posible obtener una tutela eficaz por otros medios menos $\operatorname{costosos}^{52}$.

Así se considera al derecho penal, como la rama del derecho a la que se debe recurrir en última instancia, es decir, la ultima ratio, en lo que al resto de parcelas del ordenamiento jurídico se refiere; al respecto, Berdugo señala:

«[...] este modo de graduar la intervención penal tras la civil y la administrativa fundamenta constitucionalmente el ya analizado carácter subsidiario del Derecho penal respecto de los demás instrumentos jurídicos cuya eficacia pretende "subsidiariamente" asegurar. A la vez, configurado el Derecho penal con esos criterios, su intervención en la protección de los bienes jurídicos aparece como fragmentaria, es decir, no los tutela frente a todos los ataques, sino ante los más graves o más peligrosos, por lo que el Derecho penal define sólo una parte de lo antijurídico o, dicho de otro modo, del conjunto de la antijuricidad el Derecho penal acota sólo un fragmento [...]" " ${ }^{53}$.

Así, esta subsidiaridad y fragmentariedad conforman lo que actualmente la doctrina penal denomina "principio de mínima intervención».

La importancia de este principio se muestra al momento de actuar los operadores penales (legislador, juez, fiscal, etc.) para perseguir una conducta. En efecto, tanto los criterios de política criminal (en el caso del legislador) cuanto los de interpretación de las normas penales (en el caso del juez o del fiscal) u otros en materia penal, deben actuar sobre la base de un criterio de mínima intervención si se quiere respetar los derechos fundamentales de los ciudadanos. En sí, el principio de

50 Jesús Silva. Aproximación al Derecho Penal Contemporáneo. Barcelona: Bosch, 1992. p. 15. El autor parafrasea el preámbulo del texto del Proyecto Alternativo del Código Penal Alemán de 1966.

51 Juan Carbonell. Op. cit. p. 34.

52 Claus Roxin. Op. cit. p. 66.

53 Ignacio Berdugo. Op, cit. p. 50. 
mínima intervención representa uno de los límites al ius puniendi, orientado a garantizar al máximo la libertad del individuo.

Lo contrario, es decir, no tomar en cuenta el principio de mínima intervención a la hora de criminalizar conductas, perseguir delitos o aplicar sanciones, significa una transgresión de las garantías de los ciudadanos, por parte del Estado. Pese a ello, en la actualidad el legislador recurre a lo que Mir denomina una «huida al Derecho penal " $^{54}$, con la sola finalidad de reprimir, intentando solucionar los conflictos sociales sin haber agotado previamente las otras ramas del ordenamiento jurídico. Es decir se toma al derecho penal como instrumento para la solución de conflictos de naturaleza obligacional, es decir civil, administrativa, laboral $\mathrm{u}$ otras.

Gráficamente, podríamos indicar que la forma cómo se han estructurado las normas en el sistema normativo corresponde a una serie de «filtro» superpuestos, para la solución de controversias; de los cuales, el Derecho penal, viene a ser el que se ha diseñado para solucionar aquellas más graves, para las cuales no se ha diseñado un "filtro" anterior.

Tanto en el contrato de prenda global y flotante, cuanto en la demora y no pago de los aportes por parte del empleador al Sistema Privado de Pensiones, se exige una respuesta al derecho, la cual es dada, como se analizará más adelante, por el Derecho civil, instancia previa al derecho penal que prevé soluciones menos gravosas que no involucran la libertad de los ciudadanos y que, de ser consecuentes con el principio aquí enunciado, debieran aplicarse antes que buscar una alternativa punitiva.

\subsection{Principio de exclusiva protección de bienes jurídicos}

La clásica afirmación que el derecho penal protege bienes jurídicos, es parcialmente cierta. De lo hasta aquí expuesto, puede desprenderse que nuestra ciencia no se encarga de proteger todos los bienes jurídicos, sino que, en virtud de los principios de subsidiaridad y fragmentariedad, sólo serán merecedores de protección aquellos bienes jurídicos de máxima relevancia para la vida en sociedad; $y$, más aún, estos bienes jurídicos serán protegidos sólo de aquellos ataques que por su gravedad ameriten la intervención penal ${ }^{55}$. 
Existe unánime aceptación de que el objeto de protección es el bien jurídico ${ }^{56}$; sin embargo, la discrepancia a nivel doctrinario se presenta al intentar definir qué es el bien jurídico sin llegarse a una posición siquiera mayoritaria ${ }^{57}$. Más aún, esta misma discrepancia, ocasiona que las diversas tendencias jurídicas (positivismo, iusnaturalismo, etc) no encuentren un punto común de donde partir de cara a la construcción de un concepto satisfactorio del bien jurídico.

«[...] ha afirmado Rudolphi que la norma fundamental es la clave que permite superar la dicotomía entre un concepto teleológico de bien jurídico (positivo, pero vacío y puramente formal) y un concepto liberal (con contenido pero previo al derecho positivo) $[\ldots]]^{58}$.

Así, en la búsqueda de una fundamentación para el concepto de bien jurídico es que se ha recurrido a la norma fundamental por ser ésta el marco valorativo sobre el cual se van a desarrollar las estructuras sociales y jurídicas de determinada sociedad.

En este sentido, Nicolás García Rivas plantea:

"[...] si el sistema penal está vinculado a la protección de intereses relevantes por exigencia constitucional, dichos intereses han de tener necesariamente un reconocimiento -más o menos explícito- en la propia constitución $[\ldots]$,...

Esta idea se ve complementada por la afirmación de Bricola, para quien la relevancia constitucional significa la no incompatibilidad con la norma fundamental, sino que este valor, bien jurídico-penal en nuestro caso, esté explícita o implícitamente enmarcado en la Constitución ${ }^{60}$.

56 Esto al margen de la posición positivista de las actuales corrientes sistémicofuncionalistas. Cfr. al respecto: Günther Jakobs. Derecho Penal. Parte General. Fundamentos y Teoría de la Imputación. Madrid: Marcial Pons, 1995. p. 43 y ss.

57 Para una explicación de dicho fenómeno vid: Claus Roxin. Op. cit. pp. 54-55.

58 Nicolás García Rivas. El poder Punitivo en el Estado Democrático. Cuenca: Ediciones de la Universidad de Castilla - La Mancha, 1996. p. 48.

59 Ibidem.

60 Citado por Nicolás García Rivas. Op. cit .p. 51. 
Sin embargo, las teorías constitucionalistas del bien jurídico se han visto sometidas a tres objeciones cuya difícil superación ha generado un desencanto en los últimos años ${ }^{61}$, estas son:

1. Se afirma que la Constitución tiene por objeto establecer las bases del ejercicio del poder político y no regular las relaciones sociales en donde se pueda lesionar algún bien jurídico penal.

2. La norma constitucional, por contener conceptos genéricos puede ser utilizada manera flexible y/o ambigua, lo que no permite concretar el interés penal protegido.

3. Que el texto constitucional contenga un catálogo cerrado de bienes objeto de protección penal contraviene un principio básico como el de pluralismo, con lo cual la discusión se centraría solamente en el plano político ${ }^{62}$.

Dichas objeciones, sin embargo, a decir de García Rivas, no son óbice para la lectura Constitucional planteada. En efecto:

Respecto de la primera objeción.- El autor citado considera, tal como se señaló al inicio del presente trabajo, que si bien la Constitución representa la plasmación de la voluntad política de un pueblo, ella también representa el marco normativo en que se encuentran los valores que orientan el devenir de la misma. Así, estos valores ameritan una protección acorde a su relevancia, protección que, por la severidad de sus sanciones, sólo puede ser brindada por el Derecho penal.

Respecto de la segunda objeción.- Para el autor precitado, esta «indeterminación" del interés protegido no es propia del concepto de bien jurídico de índole constitucional, sino de cualquier concepto de bien jurídico. Por lo que los ataques contra los mismos, deben ser objeto de un posterior desarrollo por parte de la doctrina ${ }^{63}$.

Respecto de la tercera objeción.- Antes que una objeción, García Rivas la considera una llamada de atención para evitar futuras interpretaciones erróneas del texto constitucional y del objeto de protección penal. Así, entiende que la norma fundamental no es un espacio cerra-

61 FIANDACA/MUSCO. La Pérdida de legitimación del Derecho penal. En: RIDPP, 1994, p. 39. Citado por Nicolás García Rivas. Op. cit. p. 51.

62 Nicolás García Rivas. Op. cit. p. 51.

63 Ibidem. 
do y estático en donde los constituyentes han consagrado las estructuras políticas y jurídicas, sino, además, es un cuerpo dinámico motivado por el consenso, el cual va a servir de motor para diseñar los futuros lineamientos de política-criminal y ampliar la gama de derechos, garantías y bienes jurídicos contenidos en el texto constitucional ${ }^{64}$.

Este trabajo creador y expansivo se ve favorecido por lo dispuesto en la cuarta disposición final y transitoria del texto Constitucional peruano, que consagra lo siguiente:

«Las normas relativas a los derechos y a las libertades que la Constitución reconoce se interpretan de conformidad con la Declaración Universal de Derechos Humanos y con los tratados y acuerdos internacionales sobre las mismas materias ratificados por el Perú».

Así, dentro de los valores consagrados y protegidos en nuestra carta fundamental se encuentra el derecho de propiedad (contenido en el artículo $70^{\circ}$ ) que, como hemos visto, debe ser interpretado a la luz de los tratados internacionales de los que el Perú es parte. Por lo cual, como veremos en el siguiente apartado, es imposible que alguna norma (como las criticadas en este trabajo) establezcan una "protección» al «bien jurídico» que respete el marco constitucional pre-citado ${ }^{65}$.

\subsection{Prohibición de cárcel por deudas}

El hecho que, generalmente, la mayor parte de los supuestos de apropiación ilícita recaiga en bienes fungibles -como el dinero- genera que este delito aparezca, frecuentemente, aplicado a personas insolventes, lo cual hace pensar en una hiper-criminalización que consiste en alen-

64 Ibidem.

65 Cabe precisar las diferencias entre bien jurídico y derecho fundamental. El derecho fundamental expresa una exigencia del ciudadano frente al estado, mientras que el bien jurídico plasma una realidad de realización de la vida social, pero como una relación concreta con el estado, en el que éste último participa al igual que lo hacen los demás ciudadanos en un determinado ámbito social. En tal sentido, el derecho fundamental sería la base referencial para un bien jurídico. Ver Alicia Gil Gil. Derecho Penal Internacional. Especial Consideración del Delito de Genocidio. Madrid: Tecnos, 1999. 
tar el derecho de los acreedores a introducirse en el patrimonio del deudor para satisfacer su crédito.

De esta manera, se castiga al deudor por no cuidar lo suficiente su patrimonio con el objeto de poder cumplir con los pagos correspondientes a las deudas contraídas. La insolvencia, o la deuda impaga a la que hacemos referencia, los «expone» a un delito de prisión por deudas que ni la ley penal ni la Constitución permiten, sino que, por el contrario, repudian.

En otras palabras, se están penalizando meros incumplimientos contractuales por la frustración de determinadas expectativas.

La esencia del delito de apropiación ilícita radica en la transmisión de la posesión a través y exclusivamente mediante un título que señala la forma y modo de devolver el bien recibido. Este y no otro es el comportamiento típico descrito en el artículo $190^{\circ}$ del C.P. Se colige, entonces, que el deudor, al no devolver el bien, no comete el delito de apropiación ilícita ya que no trasmitió ni la propiedad ni la posesión del bien prendado.

Es, precisamente, el delito de apropiación ilícita el límite extremo de la ley penal, más allá corresponde a la esfera de las relaciones del Derecho Civil. Para evitar interpretaciones extensivas y, por lo tanto, abusivas conviene connotar que con esta ampliación del delito de apropiación ilícita solamente se ampara el contenido del título por el que se detenta el derecho del acreedor a la satisfacción del crédito con el patrimonio del deudor, lo cual es materia de una discusión extrapenal.

Obviamente la apropiación ilícita genera problemas que deben tomarse en cuenta al momento de fijar los límites de lo que se encuentra dentro o fuera de sede penal. No es suficiente la simple obligación de restituir para que esta conducta sea punible.

Lo que trata de evitar la norma jurídico penal descrita en el Artículo $190^{\circ}$ del C.P. es la incorporación ilícita de un bien mueble ajeno mediante el abuso de confianza luego de haberlo recepcionado mediante un título válido (contrato de depósito, administración, comisión, u otro título semejante a éstos), ya que cualquiera (de estos contratos) sustenta la obligación de restituir, convirtiéndolo en punible en caso de que el comportamiento se subsuma en lo descrito por el tipo, pues de no darse estos elementos del tipo, no se configura el delito de apropiación ilícita. 
Cabe mencionar que la no prisión por deudas ha sido acogida por el Pacto Internacional de Derechos Civiles y Políticos (Artículo 11\%) que dispone:

«Nadie será encarcelado por el sólo hecho de no poder cumplir una obligación contractual».

Y por la Convención Americana sobre Derechos Humanos, artículo $7^{\circ}$ :

«Nadie será detenido por deudas. Este principio no limita los mandatos de autoridad judicial competente dictados por incumplimiento de deberes alimentarios».

De tal forma que este principio importa un derecho fundamental, y es éste el sentido e importancia que debe al literal c, del inciso 24, del Artículo $2^{\circ}$ de la Constitución:

«No hay prisión por deudas. Este principio no limita el mandato judicial por incumplimiento de deberes alimentarios».

Cabe agregar que la excepción a este principio lo constituye el incumplimiento de deberes alimentarios debidamente reconocido y exigido en sede judicial.

Una obligación se configura al momento que un sujeto, el deudor, se encuentra obligado por una prestación a su contraparte en esta relación jurídica, el acreedor. Este acreedor posee un «[...] crédito consistente en el derecho a que el deudor le pague dicha prestación [...] ${ }^{66}$. Siendo esta prestación "[...] algo que el deudor debe o bien dar al acreedor, o bien hacer o no hacer para el acreedor $[\ldots] n^{67}$.

La deuda no conlleva, o no debería conllevar anexa la interdicción civil. El principio de subsidiaridad y fragmentaridad, que en otro momento ya fue explicado, es uno de los motivos por los que estas acciones no deben ser consideradas dentro de lo penalmente relevante. Existen otros medios más eficaces para solucionar estos problemas,

66 Marcial Rubio Correa. Estudio de la Constitución Política de 1993. Tomo 1. Lima: Fondo Editorial de la P.U.C.P. 1999. p. 458.

67 Ibidem. 
herramientas como las que tiene a su disposición el derecho civil son las idóneas para resolver estos conflictos.

El principio de prohibición de cárcel por deudas tiene una larga historia en nuestros textos constitucionales, siendo la carta de 1828 , en su artículo $128^{\circ}$, la última que penaba la deuda como meritoria de prisión.

«Una ley determinará los casos en que haya lugar a prisión por deudas".

A partir de la Constitución de 1920, en su vigésimo quinto artículo, se prohibía la cárcel por deudas, costumbre que perduró hasta hoy en día.

«Nadie podrá ser apresado por deudas».

Es importante destacar el logro que significó para la libertad individual limitar el ámbito de punición y deslindar el incumplimiento de una deuda. Esto, debido al precedente histórico que condena su inclusión como tipo penal, ya que a través de este instrumento se alentaba al acreedor el reducir a la "persona" a una garantía e incluso disponer de ella (enajenarlo) en caso de incumplimiento de la obligación adquirida.

«[...] En épocas antiguas del Derecho Romano, existía inclusive un mecanismo judicial mediante el que el deudor incumplido caía bajo el poder de su acreedor hasta que pagaba lo que debía. Inclusive, éste podía venderlo $[\ldots]{ }^{68}$.

Como podemos observar esto significó una facultad ilegítima (desde nuestra perspectiva) otorgada a un particular de tratar a un par como un bien, lo cual podría ser aceptado sólo en una sociedad donde la esclavitud (la posibilidad de suprimir la condición de persona) era permitida. Abolida la esclavitud y elevado el ser humano a valor esencial de la sociedad (como lo consigna nuestra Constitución en su primer artículo: «[...] La defensa de la persona humana y el respeto de su dignidad son el fin supremo de la sociedad y del Estado [...]"), esta figura es ya inadmisible. 
Sin embargo, la posibilidad de que el derecho penal regule el pago de deudas, bajo el camuflaje de la perpetración de una apropiación ilícita, mediante su poder punitivo, significaría atentar contra la seguridad jurídica del ciudadano. Esto, porque en la sociedad liberal de hoy, el mercado es quien rige las relaciones económicas entre los individuos a través del constante intercambio de bienes, relaciones que conllevan una serie de riesgos a los cuales el agente económico está expuesto y asume tal exposición como supuesto previsto. Por lo tanto, penalizar el incumplimiento del pago de la deuda implicaría extender el ius punendi a gran parte de la ciudadanía ya que un riesgo común y constante es el quedar endeudado por contraer obligaciones que luego no se pueden solventar; de este modo, la libertad de contratar e intercambiar se verían limitadas debido al temor que la intromisión penal generaría en los individuos. Finalmente, penar el incumplimiento, desde una visión realista y pragmática escaparía a las posibilidades del sistema penitenciario y truncaría el libre tráfico en una sociedad de consumo, ya que ésta sería imposible sin deudores.

Como bien señala Rubio Correa: «[...] la deuda es un problema privado entre acreedor y deudor y no es un problema de la sociedad que deba ser sancionado con una pena ${ }^{69}$. La naturaleza jurídica de toda responsabilidad contractual es civil y no penal (siempre que no se configure el delito de estafa; caso en el que no se penaliza la deuda, sino la forma en que esta obligación se ha incumplido). La idea que las deudas se deben proscribir en sede penal encuentra amparo en un derecho liberal, que no busca inmiscuirse tanto en el quehacer de los sujetos privados.

Como señala Bernales Ballesteros:

«[...] Es un principio del derecho liberal moderno separar las obligaciones de carácter civil de la pena de privación de la libertad porque, [...] incumplir una obligación no es un delito y en consecuencia al moroso no le corresponde una pena de esta naturaleza $[\ldots]{ }^{70}$. 


\section{Función del juez penal frente a los problemas planteados}

\subsection{Procedencia del control difuso}

El deber de todos los tribunales que deriva del método difuso de control de la constitucionalidad de las leyes, implica el deber de dar preferencia a la Constitución y, en consecuencia, de inaplicar las leyes que consideren inconstitucionales; implica que este deber judicial sólo puede ser cumplido dentro un proceso concreto, el cual es materia de conocimiento por parte del juez, y donde la inconstitucionalidad de la ley o norma no es ni el objeto de dicho proceso ni el asunto principal del mismo.

En tal sentido, para que se pueda ejercer el control difuso de la constitucionalidad de las leyes, siempre tiene que existir un proceso en cualquier materia, por lo que siempre es un sistema incidental de control, en el sentido de que la cuestión de inconstitucionalidad de una ley y su inaplicabilidad, deben plantearse en un caso o proceso concreto, cualquiera sea su naturaleza, en el cual la aplicación o no de una norma concreta es considerada por el Juez como relevante para la decisión del caso. En consecuencia, en el método difuso de control de constitucionalidad, el objeto principal del proceso y de la decisión judicial no es la consideración abstracta de la constitucionalidad o inconstitucionalidad de la ley o su aplicabilidad o inaplicabilidad, sino más bien, la decisión de un caso concreto cualquiera sea su carácter.

$\mathrm{Al}$ respecto debemos indicar que, se trata de un deber de los jueces el aplicar la Constitución en un caso concreto e inaplicar, para su decisión, la ley que consideren inconstitucional; los jueces deben considerar de oficio las cuestiones de constitucionalidad, de tal forma que, cualesquiera sea su posición jerárquica, están facultados para revisar y verificar, dentro de un determinado caso de su competencia, si sus resoluciones se ajustan a lo preceptuado en la Ley Fundamental.

\subsection{Efectos jurídicos del control difuso}

Respecto a los efectos que el control difuso de constitucionalidad produce en un caso concreto, se debe indicar que responden a varios aspectos. 
En primer lugar, la racionalidad de este método es que la decisión adoptada por el Juez únicamente tiene efectos en relación a quienes constituyen partes en el proceso concreto en la cual aquella se adopta. En otras palabras, la decisión adoptada en un caso sobre la inconstitucionalidad e inaplicabilidad de la ley, sólo produce efectos en relación al caso concreto y exclusivamente en relación a las partes que han participado en éste, por lo que no puede ser aplicada a otros particulares. Esta es la consecuencia directa de la aplicación del control difuso.

Entonces, no debe entenderse que, si una ley es considerada inconstitucional en una decisión judicial, dicha ley ha sido invalidada y no será efectiva o inaplicada para otros casos. Sólo significa que en cuanto concierne a ese proceso particular y a las partes que en él intervinieron (en el cual el juez decidió la inaplicabilidad de la ley), ésta debe considerarse inconstitucional, nula y sin valor, sin que ello tenga ningún efecto en relación a otros procesos, otros jueces y otros particulares.

Cuando un juez decide sobre la inconstitucionalidad de una ley, y deja de inaplicarla en un caso concreto, es porque la considera nula y sin valor para efectos concretos. Por ello es que se dice que la decisión del juez es de carácter declarativa: no considera válida a la norma inconstitucional en su aplicación al interior del proceso. Esto para los casos en que dicha norma no permita alguna interpretación coherente con los postulados constitucionales.

Por tanto, en estos casos de control constitucional difuso, los jueces no pueden anular la ley sino considerarla inconstitucional, no pudiendo los efectos de su decisión extenderse o generalizarse a otros casos o sujetos. En el mismo sentido, tal como sucede en todos los sistemas de control judicial difuso, el Juez debe limitarse a decidir la no aplicación de la ley inconstitucional en el caso concreto, por supuesto, sólo cuando ello resulta pertinente para la resolución del caso.

Por esta razón, la ley que ha sido inaplicada en un caso concreto, sigue vigente, y otros jueces pueden seguir aplicándola. Inclusive, el juez que decide no aplicar la ley en un caso concreto, podría cambiar de opinión en un juicio posterior.

Por otra parte, no se deben descuidar los efectos prácticos que se producen a consecuencia de la aplicación de este control de constitucionalidad de las leyes, toda vez que las decisiones tomadas no son uniformes y en tal sentido pueden originar incertidumbre de orden legal y posibles contradicciones en su interpretación. 


\subsection{Problemas de interpretación de la norma constitucional}

Hay jueces que motivados por las palabras de Montesquieu «el juez es la boca a través de la cual hablan las palabras de la ley" han pretendido racionalizar el orden jurídico divinizándola al considerar que representa a la voluntad popular, motivo por el que se han ajustado al sentido literal de cada precepto, lo cual puede traer consecuencias nefastas, ya que, como afirma Canosa:

«[...] el derecho se sabe, en ocasiones, incierto, y el modo más a su alcance para conservarse es aplicarse bajo reglas estrictamente racionalizadas; ya que la ley puede ser injusta o estar equivocada (esto, como hemos visto, se oculta con la falacia de la perfección de la ley). Al menos, evitemos que el juez pueda añadir nuevos errores [...]” ${ }^{71}$.

Es por ello que mediante la interpretación, el sujeto busca el sentido y el alcance normativo de un texto. Así, interpretar es preparar el camino que producirá en cada caso la norma concreta y finaliza cuando el sujeto intérprete decide entre las probables alternativas. En tal sentido, el intérprete aplicará y fundamentará su decisión, la cual es fruto de la labor hermenéutica, y sólo se materializa cuando se resuelve el caso concreto. En ese orden de ideas, se resolverá el caso extrayendo de la disposición general la norma individual pertinente.

Como anota Huerta Guerrero "[...] no debe escapar al intérprete de toda constitución que ésta refleja un acuerdo político determinado en un particular momento histórico, rodeado de singulares características que, de acuerdo a la dinámica social, pueden variar $[\ldots]{ }^{72}$. Lo que puede hacer ver nuestra investigación como conservadora en tanto se "límite" a la protección de un bien jurídico tradicional como es la propiedad, desatendiendo, aparentemente, nuevas figuras creadas para viabilizar nuevas formas de relaciones crediticias u obligaciones laborales. Sin embargo, consideramos que no es el camino adecuado implementar figuras laborales o civiles que tengan por único objetivo

71 Raúl Canosa Usera. Interpretación Constitucional y fórmula política. Madrid: Centro de Estudios Constitucionales, 1988. p. 10.

72 Luis Alberto Huerta Guerrero. Derechos fundamentales e interpretación constitucional. Lima: C.A.J., 1997. p. 24. 
el de aparentar la resolución del conflicto particular mediante leyes efectistas mas no efectivas y a costa de vulnerar derechos constitucionales que han sido inclusive materia de tratados internacionales como es la no prisión por deuda o por incumplimiento de contrato, que es el quid de toda esta discusión.

En tal sentido creemos que el juez que interprete las normas constitucionales, en primer lugar, debe encontrar la fórmula política de la Constitución, la que no es otra que la expresión ideológica que organiza la convivencia social ${ }^{73}$. A la par, la interpretación constitucional ha de orientarse a mantener la seguridad jurídica y la vigencia del estado de derecho, lo cual significa (como son las leyes que nos convocan) que pueden ser dejadas de lado en razón a la imposibilidad de interpretarlas conforme a las normas recogidas en la Constitución.

Es de tomarse nota, sin embargo, de la existencia de varias interpretaciones, razón por la cual, puede generarse una jurisprudencia dispar. Sin embargo, siendo que la teoría de la interpretación constitucional constituye el núcleo central de la teoría de la Constitución, no habrá una solución única y excluyente para cada caso. Lo importante es que ella sea razonable, coherente y consistente, para lo cual existen diferentes principios ${ }^{74}$.

Si bien es cierto que la interpretación de las normas con rango de ley están investidas de subjetivismo, lo cual hace que también lo esté toda la actividad judicial, creemos que la interpretación del juez debe estar delimitada no sólo por el control social a posteriori, que, según Balaguer, debe mediar entre la resolución judicial y su aceptación posterior ${ }^{75}$. Además debe tenerse en consideración ciertas pautas generales, algunas de las cuales ya hemos mencionado, a las que debe añadirse

73 Pablo Lucas Verdu. Curso de Derecho Político. Tomo II. Madrid: Tecnos, 1986. p. 532.

74 Domingo García Belaunde. Interpretación Constitucional como Problema. En: Anuario de Derecho Constitucional Lationoamericano. Bogotá: CIEDLA, Fundación Conrad Adenauer, 1996. p. 82. (Citado por Sanuel Abad Yupanqui. Los derechos humanos y la Constitución: La necesaria influencia de la Declaración Universal de los Derechos Humanos. En: Fabián Novak y Juan José Ruda. Declaración Universal de los Derechos Humanos, 50 años. Lima: Fondo Editorial PUCP, 1999. p. 153).

75 María Luisa Balaguer Callejón. La interpretación de la Constitución por la Jurisdicción Ordinaria. Madrid: Civitas, 1990. p. 61. 
las propuestas por Wrobleswy según quien la interpretación constitucional es aquella que es funcional, es decir, la que se relaciona con una idea general sobre el derecho y la sociedad y una teoría global de la dependencia social del derecho ${ }^{76}$, toda vez que el problema fundamental no está en los sujetos, sino en la concepción de la ley y en la ordenación del conjunto que hace un sistema normativo y, por supuesto, en la aplicación de la ley. Otro de los postulados genéricos se circunscribe a que la interpretación de la ley y del ordenamiento conforme a la Constitución obliga al sometimiento del juez a un sistema de valores y de principios expresos que deben orientar la aplicación del derecho, valores y principios establecidos en la Constitución, los cuales no son fáciles de ser interpretados porque las normas constitucionales suelen tener una estructura abierta. Aún así, los jueces están obligados a extraer el sentido material de la Constitución.

En cuanto a los postulados concretos a tener en consideración por el juez, creemos que el sometimiento obligado al precedente (stare decisis) no debe ser asumido de manera estricta en tanto que la judicatura, como las normas, debe adaptarse a las nuevas circunstancias sociales, lo que va a significar que jurisprudencia es evolutiva. Ello no significa un salto al vacío, esto es, que por adoptar posturas modernas o acatar ciegamente la intervención del poder público en la sociedad se aplique literalmente aquellas nuevas leyes para la resolución de conflictos privados, más aún cuando el derecho penal tiene por función la garantía de derechos traducidos en bienes jurídicos. El límite de la intervención estatal, en toda organización social, a ámbitos específicos de relación entre particulares radicará en la necesidad de intervenir para asegurar un funcionamiento mínimamente armónico de la estructura social, de forma tal que las relaciones entre privados solamente serán objeto de atención pública cuando provoquen una lesión o puesta en peligro de bienes considerados objeto de protección necesaria en el ámbito penal. Canosa da algunas bases concretas para la hermenéutica judicial:

1. Sus decisiones han de ir precedida de una motivación. Sólo algunos autos de mero trámite y, por ende, de escasa importancia, carecen de ella.

76 J. Wrobleswy. Constitución y Teoría General de la interpretación jurídica. Madrid: Civitas, 1985 . p. 36. 
2. Su alcance, con la excepción del precedente, y aún así esto también es relativo, es particular, solamente para un caso y una materia concreta.

3. Su acción es generalmente inducida y cuando actúan de oficio se ven limitados por numerosas regulaciones de su conducta.

4. La influencia de la interpretación judicial se asienta no tanto en un poder físico, real, sino más bien moral, consentimiento difuso de los ciudadanos.

5. A la práctica judicial corresponde, en última instancia velar y garantizar el orden jurídico de cara al respeto de la Constitución (estado constitucional)

Finalmente es necesario que la labor hermenéutica respete algunos principios como son:

a. Principio de unidad de constitución.- La constitución debe entenderse de modo integral y no como formada por compartimientos estancos. El análisis de cada disposición contenida en la Carta Magna se realizará tomando en consideración sus demás normas.

b. Principio de la concordancia práctica.- Que invoca la necesidad de coherencia entre las distintas normas que integran el sistema constitucional, de tal forma que los bienes jurídicos protegidos en la Constitución deben ser compatibles con la solución de los problemas interpretativos; lo cual obliga a efectuar una ponderación de bienes para resolver los conflictos, si fuera el caso de darse entre los diversos valores recogidos en la Constitución.

c. Principio de eficacia integradora.- La interpretación debe estar orientada a reforzar la unidad política de la norma constitucional.

d. Principio de corrección funcional.- La interpretación no debe interferir con las funciones que asigna la Constitución a los diferentes órganos del estado. La interpretación debe respetar la distribución de funciones estatales señaladas en el Texto Fundamental.

e. Principio de eficacia o efectividad.- La opción hermenéutica del interprete debe ser aquella que optimice la eficacia de las normas constitucionales, sin distorsionar su contenido y actualizándolas ante los nuevos cambios sociales ${ }^{77}$. 
Cabe señalar que no se pretende desconocer la importancia de la relación comercial o laboral existente detrás de las leyes materia de análisis, nuestra preocupación radica en criticar una postura facilista del legislador de pretender resolver meros incumplimientos de pago con la utilización del derecho penal, echando mano en este caso, de la figura de la Apropiación Ilícita.

\section{Conclusiones}

1. El bien jurídico protegido por el delito de Apropiación Ilícita, "patrimonio", no alcanza a ser objeto de protección en lo dispuesto en la ley que regula la prenda global y flotante y en la ley que regula las aportaciones a las AFP.

2. Las leyes submateria de análisis encuentran en sede civil y laboral la resolución a los casos en conflicto que se presenten, motivo por el cual, al recurrirse al derecho penal, éste tendrá sólo un efecto simbólico.

3. El referente de todo bien jurídico es la Constitución, por ser el marco adecuado de donde se van a extraer los valores materia de protección penal. Así, el derecho de propiedad, al estar previsto en la norma fundamental, cumple con este requisito; sin embargo, en virtud del carácter fragmentario del derecho penal, tal protección no puede realizarse in extenso para el pago de una acreencia, sino delimitada, como en el caso de la apropiación ilícita, a ciertos aspectos, como es la libre disponibilidad del bien, respetándose la forma del comportamiento típico.

4. Las leyes submateria de análisis lesionan los principios de legalidad, lesividad, mínima intervención, entre otros, motivo por el cual devienen en inconstitucionales. A la par, los comportamientos allí descritos no podrán ser materia de represión por el tipo de Apropiación Ilícita por la imposibilidad de subsumirlos.

5. El juez penal se encuentra en la obligación de solucionar los problemas generados por estas dos leyes inconstitucionales, mediante el control difuso de la constitucionalidad. Para ello, debe asumir el papel de intérprete de las normas constitucionales, acatando ciertos principios y atendiendo a ciertas pautas, para alcanzar una resolución racional, coherente y consistente. 
6. Las leyes submateria de análisis, además de ser inconstitucionales, de abandonar la protección a bienes jurídicos, importan la reinstauración de la cárcel por deudas.

\section{Bibliografía básica}
A. Libros

\section{ALCABES NISSIM}

1999 Aportes a una ley orgánica del poder judicial: La carrera judicial, evaluación del desempeño de los magistrados judiciales, estructura y gobierno del poder judicial. Lima: News Graff.

AVENDAÑO, Jorge

1996 Selección de textos. Derechos Reales. Lima: Oficina de Publicaciones para la Docencia de la PUCP.

BAJO FERNÁNDEZ, Miguel

1985 La Determinación de la Pena en el Delito de Apropiación Indebida. En: Comentarios a la Legislación Penal. V-2.

BALAGUER CALLEJON, María Luisa.

1990 La Interpretación de la Constitución por la Jurisdicción Ordinaria, Madrid: Cívitas.

BELTRAN BALLESTER, El Hurto de Hallazgo. 1979 Valencia.

BERDUGO GOMEZ DE LA TORRE, Ignacio y Otros

1997 Lecciones de Derecho Penal. Parte General. Barcelona: Praxis.

BIDART CAMPOS, Germán

1967 El Derecho Constitucional del Poder. Buenos Aires. Ediar. 2 Tomos 
BIDART CAMPOS, Germán

1987 La Interpretación y el Control Constitucional en la Jurisdicción Constitucional. Buenos Aires: Ediar. 353 pág.

BISCARETTI DI RUFFIA, Paolo

1973 Derecho Constitucional. Madrid: Tecnos.

BOBBIO, Norberto

1993 Teoría General del Derecho. Tr. Eduardo Rozo Acuña. Madrid: Debate, 1993.

Bramont-Arias Torres, Luis y María del Carmen Garcia Cantizano 1998 Manual de Derecho Penal. Parte Especial. Lima: San Marcos.

BUSTOS RAMIREZ, Juan

1991 Manual de Derecho Penal. Parte Especial. Barcelona: Ariel.

CANOSA USERA, Raúl.

1988 Interpretación Constitucional y Fórmula Política. Madrid:

Centro de Estudios Constitucionales.

CARBONELL MATEU, Juan Carlos

1996 Derecho Penal: Concepto y principios constitucionales. Valencia: Tirant Lo Blanch.

CASTAÑEDA PALOU

Incumplimiento Contractual y Responsabilidad Penal.

Sobre la Ley de Venta a Plazos de Bienes Inmuebles.

\section{DELGADO LÓPEZ}

1985 La doctrina del tribunal supremo sobre la falta de ingreso en las cuotas obreras de la seguridad social retenidas por el empresario. En: ADPCP.

Derechos Fundamentales e Interpretación Constitucional

1997 Comisión Andina de Juristas, 1997. 
DÍAZ PALOS

1969 "Posesión de muebles y apropiación indebida". En: Libro homenaje a Castán Tabeñas, vol. III.

DIEZ - PICASO, Luis

Régimen Constitucional del Poder Judicial. Madrid. La Ley. 160 pág.

GARCÍA BELAUNDE, Domingo y Francisco FERNÁNDEZ SEGADO 1997 (compiladores). Jurisdicción Constitucional en Iberoamérica. Madrid. Dykinson.

GARCÍA BELAUNDE, Domingo

1999 Cómo Estudiar Derecho Constitucional, una década más tarde. Lima. Instituto Iberoamericano de Derecho Constitucional.

GARCÍA BELAUNDE, Domingo

2000 De la Jurisdicción Constitucional al Derecho Procesal Constitucional. Lima: Grijley. 2000.

GARCÍA DE ENTERRIA, Eduardo. La Constitución como norma y el Tribunal Constitucional. Madrid: Civitas, 1985

GARCÍA RIVAS, Nicolás. El poder Punitivo en el Estado Democrático. Cuenca: Ediciones de la Universidad de Castilla - La Mancha, 1996.

GARCÍA VIZCAÍNO, José. El Delito de Evasión Fiscal. Buenos Aires. Abeledo - Perrot. 1961.

HUERTA GUERRERO, Luis Alberto. Derechos Fundamentales e Interpretación Constitucional. Lima: C.A.J., 1997.

JAKOBS, Günther. Derecho Penal. Parte General. Fundamentos y Teoría de la Imputación. Madrid: Marcial Pons, 1995. 
LAMA, Miguel Antonio de. Diccionario Penal de Jurisprudencia y de Legislación. Lima. 1989.

LANDA ARROYO, César y Julio FAÚNDEZ (editores). Desafíos Constitucionales. Lima. Fondo Editorial de la Pontificia Universidad Católica del Perú. 1996.

LOWENSTEIN, Karl. Teoría de la Constitución. Barcelona: Ariel, 1976.

LUCAS VERDU, Pablo

1986 Curso de Derecho Político. Tomo II. Madrid: Tecnos.

MAURACH, Reinhart y Heinz ZIPF.

1987 Derecho Penal. Parte General. Tomo I. Buenos Aires. Astrea.

MENDOZA ESCALANTE, Mijail

2000 Los Principios Fundamentales del Derecho Constitucional Peruano. Lima. Gráfica Bellido.

MILLER, Jonathan y Otros

4987 Constitución y Poder Político. Tomo I. Lastrea.

MIR PUIG, Santiago

1996 Derecho Penal, Parte General. Cuarta Edición. Barcelona: PPU.

MIROQUESADA RADA, Francisco

1990 Democracia Directa y Derecho Constitucional. Lima: CONCYTEC.

MONTOYA, Iván

1997 Poder Judicial y Estado Democrático de Derecho en el Perú. Lima. Instituto de Defensa Legal. 
MORENO VERDEJO Y MARCHENA GÓMEZ

1998 El Delito de Apropiación Indebida en el Código Penal de 1995. Jurisprudencia.

MUÑOZ CONDE, Francisco

1996 Derecho Penal. Parte Especial. Valencia: Tirant Lo Blanch.

MUÑOZ CONDE, Francisco

1998 Derecho Penal. Parte General. Valencia: Tirant lo Blanch.

MUÑOZ CONDE, Francisco

1989 Aspectos jurídico-penales de la no evolución de las cantidades entregadas a cuenta para la construcción de viviendas. Madrid.

MUÑOZ MACHADO, Santiago

1989 La Reserva de Jurisdicción. Madrid: La Ley. 160 pág.

NOVAC, Fabián y Juan José RUDA (editores)

1999 Declaración Universal de los Derechos Humanos, 50 años. Lima: Fondo Editorial PUCP.

PIEPERS, M.C.

s/f La Reforma del Derecho. Madrid. La España Moderna.

POLITOFF LIFFSCHITZ (actualizado por Rivacoba y Rivacoba)

El Delito de Apropiación Indebida.

POWER MANCHEGO MUÑOZ, Jorge

1984 Constitución y Justicia. Lima: Andina. 1984.

QUERALT, Joan

1996 Derecho Penal Español. Parte Especial. Barcelona: Bosch.

QUIROGA LEÓN, Aníbal

1990 Control de Constitucionalidad: El Proceso y la Jurisdicción Constitucional. Lima: Fondo Editorial de la Pontificia Universidad Católica del Perú. 
RODRIGUEZ DEVESA, José María

1996 Derecho Penal. Parte Especial. Madrid: Dikynson.

ROXIN, Claus

1997 Derecho Penal. Parte General. Fundamentos. La Estructura de la Teoría del Delito. Tr. Diego-Manuel Luzón Peña y Otros. Madrid: Civitas, 1997.

RUBIO CORREA, Marcial

1999 Estudio de la Constitución Política de 1993. 5 Tomos. Lima: Fondo Editorial de la P.U.C.P.

RUBIO LLORENTE, Francisco

1993 La Forma del Poder (estudio sobre la constitución). Madrid. Centro de Estudios Constitucionales. 689 pág.

SERRANO GOMEZ, Alfonso

1999 Derecho Penal. Parte Especial. Madrid: Dikynson.

SILVA, Jesús

1992 Aproximación al Derecho Penal Contemporáneo. Barcelona: Bosch.

TARANTINO, Jacinto

1983 Las Penalidades Tributarias. Buenos Aires. Depalma.

VIVES ANTÓN, Tomas

1996 Comentarios al Código Penal de 1995. 2 volúmenes. Valencia: Tirant lo Blanch.

WROBLESWY, J.

1985 Constitución y Teoría General de la Interpretación Jurídica. Madrid: Civitas.

B. Artículos 
DUVERGER, Maurice.

1994 El Derecho Constitucional. En: Derecho Constitucional y Teoría del Estado. Lima.

EDER PHAMOR, J.

1960 Judicial Review in Latinoamerican. En: Ohio State Law Journal. Vol 21. Pág. 570 y sig.

EGUIGUREN PRAELI, Francisco.

1998 Relaciones entre el Poder Judicial y el Tribunal Constitucional en el Perú: la evolución del modelo y los nuevos problemas. En: Pensamiento Constitucional. Año V, No 5. Noviembre. Pág. 115 - 134.

HAURIOU, André

1994 Objeto y Significación del Derecho Constitucional. En: Derecho Constitucional y Teoría del Estado. Lima.

HESSE, Konrad

1998 Etapas del Desarrollo de la Jurisdicción Constitucional Alemana.. En: Pensamiento Constitucional. Año V, No 5. Noviembre,8. Pág. 21 - 46.

LANDA ARROYO, César.

1995 Del Tribunal de Garantías al Tribunal Constitucional: el caso peruano. En: Pensamiento Constitucional. Diciembre. Pág. 73 y sig.

PIZARRO ARANGUREN, Luis

1996 "Aproximación al sistema de garantía prendaria en el Derecho peruano". En: Ius Et Veritas Nro. 13. Año VII. Pág. 133.

SILVA SÁNCHEZ, Jesús María

1994 Política criminal y Sida. En: Revista Peruana de Ciencias Penales, Año II, enero-julio, pág. 347-348. 
C. Tesis

LOVATÓN PALACIOS, Miguel David

1999 Los Principios Constitucionales de la Independencia, Unidad y Exclusividad Jurisdiccional. Tesis de maestría con mención en Derecho Constitucional en la PUCP. Lima.

RAMÍREZ-GASTÓN BALLÓN, José Luis Germán.

1978 La Prenda Flotante. Tesis para obtener el grado de bachiller en derecho. Pontificia Universidad Católica del Perú. 